\title{
Common Types of Vaginitis (Bacterial Vaginosis, Vulvovaginal Candidiasis, Trichomoniasis) and their Association with Urinary Tract Infection among Women Visiting NMCTH, Birgunj
}

\author{
Ravi Shankar Gupta ${ }^{1 *}$, Dipak Bhargav ${ }^{1}$ and Jagat Prasad Deep ${ }^{2}$ \\ ${ }^{1}$ Department of Microbiology, ${ }^{2}$ Department of Obstetrics and Gynaecology, National Medical \\ College, Birgunj, Nepal \\ *Corresponding author
}

\section{Keywords}

Bacterial vaginosis, Urinary tract infection, Vaginitis, Vulvovaginal Candidiasis

\section{Article Info}

Accepted: 12 December 2020 Available Online: 10 January 2021
Vaginal symptoms and urinary tract infection are one of the most common reasons for gynecological consultation. Despite the differences between the organism that cause vaginitis and UTI, it is possible that women having vaginitis develop UTI. The main objective of this study was to find the association of the common types of infectious vaginitis with UTI. A study was conducted among women of reproductive age attending outpatients of Gynaecology and Obstetrics department of National Medical College Teaching Hospital, Birgunj, Nepal. The study was conducted from August 2019 to July 2020. Among 400 females, 118 were pregnant and 282 were non pregnant women .Out of 400women, 134 (33.5\%) had vaginitis and among them 49.3\% had Bacterial vaginitis (BV), $40.3 \%$ had Vulvovaginal candidiasis (VVC) and 10.7\% had mixed infection (both $\mathrm{BV}$ and VVC). There were no any cases of Trichomoniasis. In the study, women of age group 21-30 were most infected $(68.7 \%)$, ( $\mathrm{p}=0.117)$. Among 400 urine sample processed, $58(14.5 \%)$ had UTI with 21-30 age group being the most prevalent, 55.17\%. Altogether 4 different bacterial species were isolated among which $E$. coli was most predominant gram negative organism and Staphylococcus aureus being the only gram positive organism. All gram negative organisms were sensitive towards Nitrofurantoin and gram positive were sensitive to Gentamicin. A strong association was revealed between vaginitis and UTI $(\mathrm{p}=0.000)$, Candida and UTI (0.003) but association between BV and UTI was statistically insignificant $(\mathrm{p}=0.231)$.

\section{Introduction}

Women undergoes through a variety of physiological changes throughout their reproductive age especially during pregnancy (Prakash and Yadav 2015).The vagina and its unique microflora form a finely balanced ecosystem, with the vaginal environment controlling the presence of microbes and the microflora, in turn, controlling the vaginal environment (Zhou 2004).Vaginal symptoms are one of the most common reasons for gynecological consultation (Owen and Clenney 2004).Abnormal vaginal discharge (changes in quantity, color and odor), may indicate vaginitis. Vaginitis literally refers to 
a non-specific inflammation of vagina (Gillespie 1994) characterized by a watery discharge with burning and itching of the vulva (Blackwell's dictionary).

The three kinds of vaginitis are Bacterial vaginosis, Vulvovaginal candidiasis and Trichomoniasis that are found in females of reproductive age (Forbes et al 2007). Bacterial vaginosis is a polymicrobial syndrome in which increase in vaginal $\mathrm{pH}$ and decrease in lactobacillus numbers is balanced by an increase of other pathogenic microorganisms such as Gardnerella vaginalis and Mobiluncusspp in higher amount (Bradshaw et al., 2005) and other organisms such as Staphylococcus, Ureaplasma, Corynebacterium, Streptococcus, Peptostreptococcus, Bactericides, Mycoplasma, Enterrococcus, Escherichia, Veiloella, Bifidobacterium and Candida can be presentbut in much lower numbers. Gardnerella vaginalis is the common cause of BV and this organism do not invade the subepithelial tissue. Bacterial vaginosis was defined by Amsel's criteria (presence of at least three of the following: homogeneous vaginal discharge, positive whiff test, $\mathrm{pH}$ $>4.5$, and clue cells observed on a Gram stained vaginal smear).

Vulvovaginal candidiasis is the fungal or yeast infection commonly caused by $C$. albicans (Eckert 2006) and a common gynaecologic illness which is not that serious but affecting 3 out of 4 women in their lifetime (Das and Neves et al., 2008). More than $40 \%$ of women would have affected by vaginal candidiasis two or more time (Ferrer 2000; Eschenbach 2004).

The illness causes a smelly, thick, whiteyellowish curdy discharge that might be followed by itching, burning and swelling. $\mathrm{VVC}$ is most commonly found in women with low immunity power and accordingly, pregnancy is one of such factors that contribute to lowered immunity (Monif et al., 2003).

Trichomoniasis vaginitis is considered as non viral, sexually transmitted disease (Prospero FD) which is caused by parasitic protozoan, Trichomonas vaginalis. The symptoms are characterized by vaginal discharge with grey or greenish yellow fluid rather frothy, foulsmelling, intense itching, edema, cervix redness, the sensation of itching, dyspreunia and postcoital bleeding, pelvic pain and urinary symptoms

Urinary tract infection (UTI) is an infection that affect urinary tract due to presence of pathogenic microorganism undergoing multiplication in urine within urinary tract and the presence of bacteria should be more than $10^{5}$ organism $/ \mathrm{ml}$ in the midstream urine sample (Jha and Bapat 2005).

The urinary tract is usually sterile and includes the organs that collects and store urine and release it from the body such as kidneys, ureter, bladder and urethra. Presence of bacteria in urine is called bacteriuria (Cheesbrough 2006). Gram negative bacteria E.coli is one of the major causative organisms in $85 \%$ of the UTI cases (Noor et al 2004).

UTI and BV are common conditions. Women with bacterial vaginosis are at increased risk for UTI. An increased vaginal $\mathrm{pH}$ has been associated with more frequent colonization with uropathogens. Bacterial vaginosis is one of the reasons for increased vaginal $\mathrm{pH}$ in sexually active women (Prasad et al., 2005). Considering the remarkable difference between the organisms that cause $\mathrm{BV}$ and UTIs, it is possible that women with BV developed urinary tract infections because of frequent sexual intercourse (Harmanli et al., 2000). 
Nepal being under developed country with low literacy, low per capita income and no formal sexual education, peoples often ignore safe sex and personal hygiene. The married women are reluctant to seek medical treatment because of the lack of privacy, lack of a female doctor at the health facility, the cost of treatment and their subordinate social status. In Nepal, very few studies have been implicated in the prevalence and therapeutic consideration of vaginitis. So it is hard to know how frequent this disease is among Nepalese women. It has been reported that one in three women wants consultation for vaginal discharge (Pradhan 2003). The findings of this study may be helpful to the people and professionals for the prevention/control and treatment of vaginitis and prevent from stillbirth, abortion, and sterility. Many women think their symptoms are normal occurrence or are reluctant to mention those (Prasad et al 2005). This study also helps to find the prevalence of vaginitis in the pregnant women, to disseminate knowledge regarding vaginitis as many are unaware of it, to fulfill the gap in research carried out in the field of vaginitis, and to focus the main cause of vaginitis and to make women aware of it so as to prevent from reinfection in future.

\section{Objectives of the study}

1. To determine the prevalence of Bacterial vaginosis, Vulvovaginal Candidiasis and Trichomoniasis and to establish association between different types of vaginitis and UTI.

\section{Materials and Methods}

\section{Study design}

It is a cross sectional study, carried out from August 2019 to July 2020which include women from age 15-60 years visiting Gynecological department of National
Medical College and Teaching Hospital, Birgunj, Nepal. Samples were tested in Microbiology department of National Medical College and Teaching Hospital, Birgunj, Nepal.

\section{Ethical approval}

Informed verbal consent was obtained from the participants prior to the study before preceding the questionnaire and specimen collection. Ethical approval was obtained from the IRC Board of National Medical College and Teaching Hospital.

\section{Inclusion and exclusion criteria}

Inclusion criteria: 400 women form age 15-60 years presenting with abnormal excessive vaginal discharge were included in the study (oral consent was taken from all women).

Exclusion criteria: Women who were menstruating or had received antibiotics in the past four weeks were excluded from study.

\section{Data collection}

Four hundred high vaginal swab and mid stream urine were examined following standard bacteriological technique. Verbal questionnaire were also filled that include information about patient age, place, pregnancy status, education level, previous history of UTI or vaginitis, and about signs and symptoms.

\section{Data analysis}

Data was analyzed using SPSS 20 version.

\section{Results and Discussion}

Among the total of four hundred females attending the Obstetrics \& Gynaecology Department of NMCTH, 134 (33.5\%) cases 
showed vaginitis. The presenting symptoms were vaginal discharge $76.5 \%$, vulvalitching and irritation $77.5 \%$, dysuria and burning micturation $51.5 \%$ and lower abdominal pain in $56 \%$ of females.

In this study, identification of BV was done on basis of Amsel's criteria. Patients with any three of these four criteria were considered positive. There was specific vaginal discharge in $93.9 \%$ and $\mathrm{pH}>4.5$ in $84.8 \%$ of positive $\mathrm{BV}$ cases whereas $84.8 \%$ whiff test was positive and in $45.4 \%$ clue cells were seen. The differences between the incidences of these criteria were highly significant, $\mathrm{p}=0.00$ $(\mathrm{p}<0.05)$.

\section{Occurrence of UTI}

Among 400 urine samples collected from females of reproductive age group attending the Obstetrics and Gynecology department of NMCTH from whom HVSs were collected 58 $(14.5 \%)$ had urinary tract infection with significant growth.

Table.1 Types of infection detected among the female

\begin{tabular}{|l|c|c|}
\hline \multicolumn{1}{|c|}{ Types Of Infection } & Frequency & Percentage \\
\hline Bacterial vaginosis (BV) & 66 & 49.3 \\
\hline Vulvovaginal Candidiasis (VVC) & $\mathbf{5 4}$ & 40.3 \\
\hline Trichomoniasis (TV) & $\mathbf{0}$ & $\mathbf{0}$ \\
\hline BV + VVC & 14 & 10.4 \\
\hline Total & 134 & 100 \\
\hline
\end{tabular}

Table. 2 Criteria of bacterial vaginosis $(n=400)$

\begin{tabular}{|c|c|c|c|c|}
\hline & $\begin{array}{l}\text { Specific } \\
\text { discharge of } \\
\text { BV }\end{array}$ & $\mathrm{pH}>4.5$ & $\begin{array}{l}\text { Positive } \\
\text { Whiff test }\end{array}$ & Clue cell \\
\hline BV present, $n=66$ & $62(93.9 \%)$ & $56(84.8 \%)$ & $56(84.8 \%)$ & $30(45.4 \%)$ \\
\hline BV absent, $n=334$ & $154(46.1 \%)$ & $108(32.3 \%)$ & $54(16.1 \%)$ & 0 \\
\hline p-value & $<0.05$ & $<0.05$ & $<0.05$ & $<0.05$ \\
\hline
\end{tabular}

Table.3 Age wise distribution of organism in infected women

\begin{tabular}{|c|c|c|c|c|c|c|c|}
\hline \multirow{2}{*}{$\begin{array}{l}\text { Age } \\
\text { group } \\
\text { (years) }\end{array}$} & \multirow{2}{*}{ Total } & \multicolumn{3}{|c|}{ Types of infection } & \multirow{2}{*}{$\begin{array}{c}\text { Positive } \\
\text { Total }\end{array}$} & \multirow{2}{*}{$\begin{array}{c}\text { Positive \% } \\
\text { Within } \\
\text { infection }\end{array}$} & \multirow[t]{2}{*}{ P-value } \\
\hline & & BV & VVC & $\mathrm{BV}+\mathrm{VVC}$ & & & \\
\hline$\leq 20$ & 52 & 8 & 10 & 2 & 20 & 14.9 & \\
\hline $21-30$ & 232 & 52 & 34 & 6 & 92 & 68.7 & \\
\hline $31-40$ & 84 & 6 & 8 & 4 & 18 & 13.4 & $>0.05$ \\
\hline $41-50$ & 22 & $\mathbf{0}$ & $\mathbf{0}$ & 2 & 2 & 1.5 & \\
\hline $51-60$ & 10 & $\mathbf{0}$ & 2 & $\mathbf{0}$ & 2 & 1.5 & \\
\hline Total & 400 & 66 & 52 & 14 & 134 & 100 & \\
\hline
\end{tabular}


Table.4 Pattern of culture results

\begin{tabular}{|l|c|c|}
\hline Growth & No of samples & Percentage of samples \\
\hline Significant growth & 58 & 14.5 \\
\hline No growth & 342 & 85.5 \\
\hline Total & 400 & 100 \\
\hline
\end{tabular}

Table.5 Bacterial isolates

\begin{tabular}{|l|l|c|c|}
\hline S.No. & Organism isolated & No of isolates & Percentage \\
\hline $\mathbf{1}$ & Gram negative bacteria & & \\
\hline 2 & Escherichia coli & 22 & 39.2 \\
\hline 3 & Klebsiella species & 16 & 28.5 \\
\hline & Enterobacter & 12 & 21.4 \\
\hline 4 & Gram positive bacteria & & \\
\hline Total & & $\mathbf{8}$ & 10.7 \\
\hline
\end{tabular}

Table.6 Age wise distribution of UTI among women

\begin{tabular}{|c|c|c|c|c|c|}
\hline \multirow{2}{*}{$\begin{array}{l}\text { Age group } \\
\text { (years) }\end{array}$} & \multirow[t]{2}{*}{ Total } & \multicolumn{2}{|c|}{ Presence of UTI } & \multirow{2}{*}{$\begin{array}{c}\text { Positive \% } \\
\text { within infection }\end{array}$} & \multirow[t]{2}{*}{ p-value } \\
\hline & & & No & & \\
\hline$\leq \mathbf{2 0}$ & 52 & 6 & 46 & 10.3 & \multirow{6}{*}{$>0.05$} \\
\hline $21-30$ & 232 & 32 & 200 & 55.17 & \\
\hline $31-40$ & 84 & 18 & 66 & 31.03 & \\
\hline $41-50$ & 22 & $\mathbf{0}$ & 22 & o & \\
\hline $51-60$ & 10 & 2 & 8 & 3.44 & \\
\hline Total & 400 & 58 & 342 & 100 & \\
\hline
\end{tabular}

Table.7 Antibiotic Susceptibility Pattern of bacterial isolates

\begin{tabular}{|c|c|c|c|c|c|c|}
\hline \multirow{3}{*}{ S.N } & \multirow{3}{*}{$\begin{array}{l}\text { Organisms } \\
\text { isolated }\end{array}$} & \multirow{3}{*}{$\begin{array}{l}\text { Antibiotics } \\
\text { used }\end{array}$} & \multicolumn{4}{|c|}{ Antibiotic Susceptibility Pattern } \\
\hline & & & \multicolumn{2}{|c|}{ Susceptible } & \multicolumn{2}{|c|}{ Resistant } \\
\hline & & & No. & $\%$ & No. & $\%$ \\
\hline \multirow[t]{9}{*}{1} & \multirow{9}{*}{$\begin{array}{l}\text { Escherichia coli } \\
\qquad \mathbf{N}=\mathbf{2 2}\end{array}$} & Ampicillin & 2 & 18.2 & 9 & 81.8 \\
\hline & & Ciprofloxacin & 7 & 63.6 & 4 & 36.4 \\
\hline & & Gentamycin & 6 & 54.5 & 5 & 45.5 \\
\hline & & Nalidixic Acid & 3 & 27.3 & 8 & 72.7 \\
\hline & & Nitrofurantoin & 11 & 100 & $\mathbf{0}$ & $\mathbf{0}$ \\
\hline & & Cortimoxazole & 4 & 36.4 & 7 & 63.6 \\
\hline & & Amikacin & 8 & 72.7 & 3 & 27.3 \\
\hline & & Ofloxacin & 7 & 63.6 & 4 & 36.4 \\
\hline & & Amoxcillin & 7 & 63.6 & 4 & 36.4 \\
\hline
\end{tabular}




\begin{tabular}{|c|c|c|c|c|c|c|}
\hline & & Ceftriazone & 5 & 45.4 & 6 & 54.6 \\
\hline & & Cefexime & 4 & 36.4 & 7 & 63.6 \\
\hline \multirow[t]{11}{*}{2} & \multirow{11}{*}{$\begin{array}{c}\text { Klebsiellaspp } \\
\mathbf{N}=16\end{array}$} & Ampicillin & 2 & 25 & 6 & 75 \\
\hline & & Ciprofloxacin & 3 & 37.5 & 5 & 62.5 \\
\hline & & Gentamycin & 4 & 50 & 4 & 50 \\
\hline & & Nalidixic Acid & 3 & 37.5 & 5 & 62.5 \\
\hline & & Nitrofurantoin & 5 & 62.5 & 3 & 37.5 \\
\hline & & Cortimoxazole & 4 & 50 & 4 & 50 \\
\hline & & Amikacin & 4 & 50 & 4 & 50 \\
\hline & & Ofloxacin & 4 & 50 & 4 & 50 \\
\hline & & Amoxcillin & 4 & 50 & 4 & 50 \\
\hline & & Ceftriazone & 4 & 50 & 4 & 50 \\
\hline & & Cefexime & 3 & 37.5 & 5 & 62.5 \\
\hline \multirow[t]{11}{*}{3} & \multirow{11}{*}{$\begin{array}{c}\text { Enterobacterspp } \\
\quad \mathrm{N}=12\end{array}$} & Ampicillin & 1 & 16.4 & 5 & 83.6 \\
\hline & & Ciprofloxacin & 3 & 50 & 3 & 50 \\
\hline & & Gentamycin & 4 & 66.4 & 2 & 33.6 \\
\hline & & Nalidixic Acid & 2 & 33.6 & 4 & 66.4 \\
\hline & & Nitrofurantoin & 5 & 83.6 & 1 & 16.4 \\
\hline & & Cortimoxazole & 0 & $\mathbf{0}$ & 6 & 100 \\
\hline & & Amikacin & 3 & 50 & 3 & 50 \\
\hline & & Ofloxacin & 2 & 33.6 & 4 & 66.4 \\
\hline & & Amoxcillin & 2 & 33.6 & 4 & 66.4 \\
\hline & & Ceftriazone & 1 & 16.4 & 5 & 83.6 \\
\hline & & Cefexime & 2 & 33.6 & 4 & 66.4 \\
\hline \multirow[t]{8}{*}{4} & \multirow{8}{*}{$\begin{array}{c}\text { Staphylococcus } \\
\text { aureus } \\
\mathrm{N}=8\end{array}$} & Penicillin & $\mathbf{0}$ & $\mathbf{0}$ & 4 & 100 \\
\hline & & Ciprofloxacin & 2 & 50 & 2 & 50 \\
\hline & & Gentamycin & 4 & 100 & $\mathbf{0}$ & $\mathbf{0}$ \\
\hline & & Nitrofurantoin & 2 & 50 & 2 & 50 \\
\hline & & Cotrimoxazole & 1 & 25 & 3 & 75 \\
\hline & & Amikacin & 3 & 75 & 1 & 25 \\
\hline & & Ofloxacin & 1 & 25 & 3 & 75 \\
\hline & & Vancomycin & 4 & 100 & $\mathbf{0}$ & $\mathbf{0}$ \\
\hline
\end{tabular}

Table.8 Association of vaginitis and UTI

\begin{tabular}{|c|c|c|c|c|}
\hline \multirow{3}{*}{ Vaginitis } & UTI & & Total & P-value \\
\cline { 2 - 3 } & Positive & Negative & & \\
\hline Positive & $\mathbf{3 6}$ & $\mathbf{9 8}$ & $\mathbf{1 3 4}$ & \\
\hline Negative & 22 & $\mathbf{2 4 4}$ & $\mathbf{2 6 6}$ & $\mathbf{0 . 0 0 0}$ \\
\hline Total & $\mathbf{5 8}$ & $\mathbf{3 4 2}$ & $\mathbf{4 0 0}$ & \\
\hline
\end{tabular}


Table.9 Association of BV and UTI

\begin{tabular}{|c|c|c|c|c|}
\hline \multirow{2}{*}{ BV } & \multicolumn{2}{|c|}{ UTI } & \multirow{2}{*}{ Total } & P-value \\
\cline { 2 - 3 } & Positive & Negative & & \\
\hline Positive & 14 & 52 & 66 & \\
\hline Negative & 44 & 290 & 334 & 0.231 \\
\hline Total & 58 & 342 & 400 & \\
\hline
\end{tabular}

Table.10 Association of VVC and UTI

\begin{tabular}{|c|c|c|c|c|}
\hline \multirow{2}{*}{ VVC } & \multicolumn{2}{|c|}{ UTI } & \multirow{2}{*}{ Total } & \multirow{2}{*}{ P-value } \\
\cline { 2 - 3 } & Positive & Negative & & \\
\hline Positive & $\mathbf{1 8}$ & $\mathbf{3 6}$ & $\mathbf{5 4}$ & $\mathbf{0 . 0 0 3}$ \\
\hline Negative & $\mathbf{4 0}$ & $\mathbf{3 0 6}$ & $\mathbf{3 4 6}$ & \\
\hline Total & $\mathbf{5 8}$ & $\mathbf{3 4 2}$ & $\mathbf{4 0 0}$ & \\
\hline
\end{tabular}

Fig.1 Flow chart of the procedurefor HVS Processing

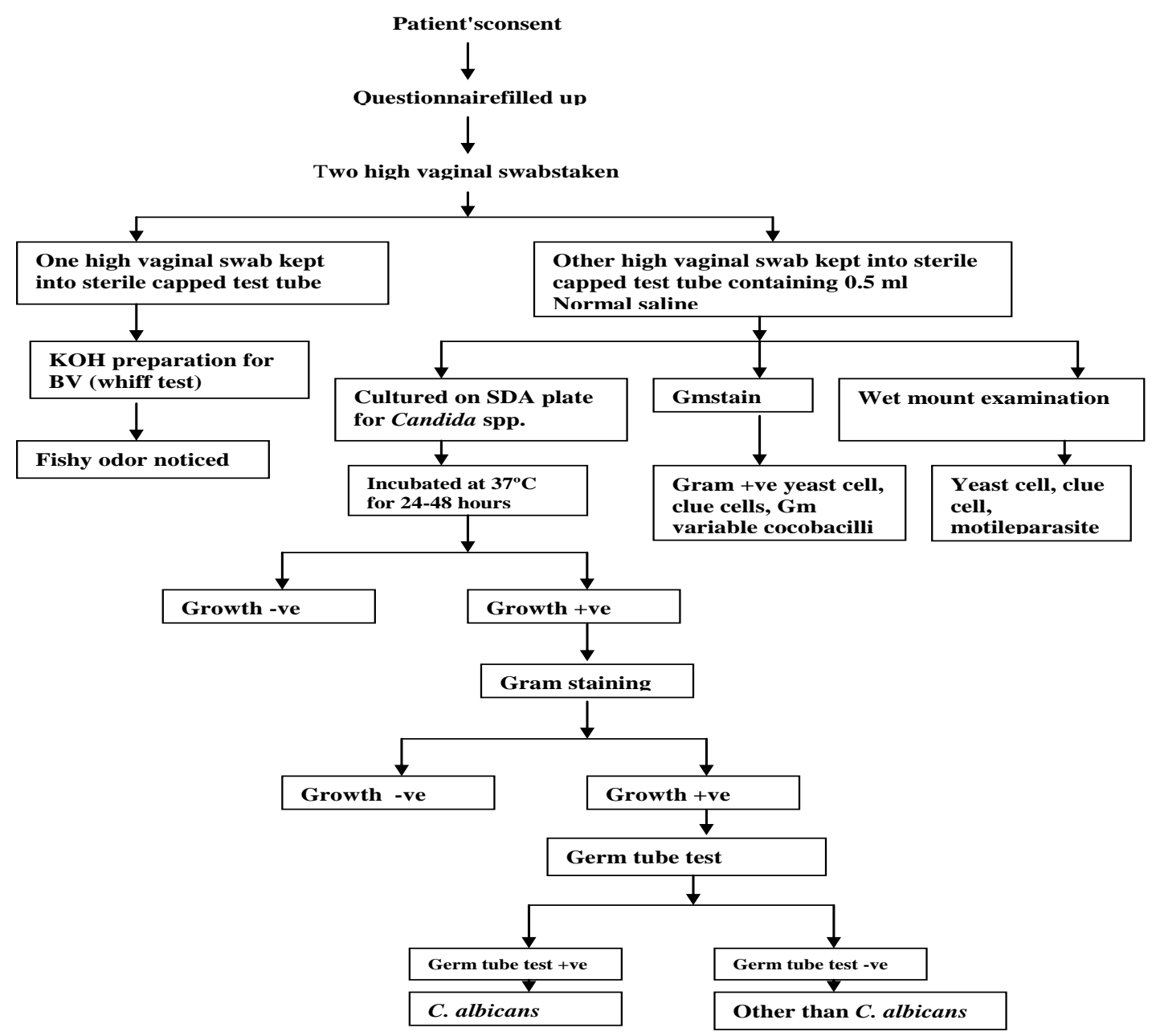


Fig.2 Flow chart of the procedure for urine processing

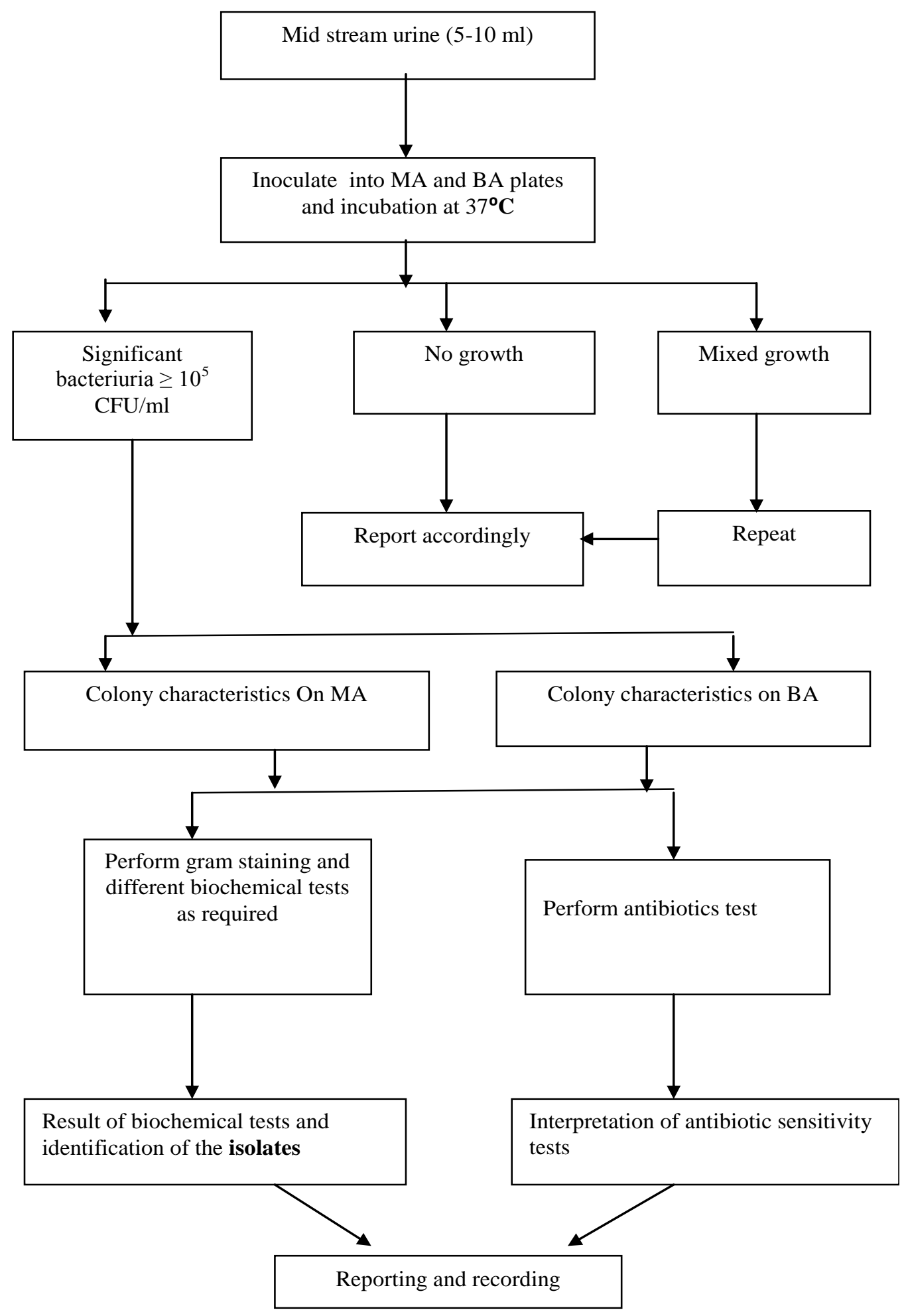


The study was carried out on women of age group from15to 60 attending to Gynae Outpatients Department (OPD) of National Medical College and Teaching Hospital, Birgunj from August 2019 to July 2020 and was restricted to 400 female patients including both pregnant and non pregnant women. In this study the prevalence of vaginitis was $33.5 \%$ which was lower than the prevalence of study done by Lamichhane et al., in 2014 (40.0\%) Bhargavetalin 2016 (46.86\%), Amatya et al., 2013 (54.24\%).

In this study among 400 females, 134 had vaginitis. Among 134 positive cases of vaginitis the Bacterial vaginosis (BV) is the highest $(49.3 \%)$ occurring vaginitis followed by Vulvovaginal candidiasis (VVC) (40.3\%) and then mixed infection (10.4\%). Similar trend of infection was reported by Kamara et alin Jamaica and Patrica et al., in Peru. The obtained result was also similar to the result reported by Shrestha et al., in 2014 in Nepal and Bhragav et al., (2016) in Nepal, Lamichhane et al., (2014) in Nepal, Pickering (2005) in Uganda. But the study results were contrary to the study conducted by Evans (1995) in London and Narayankhedkar et al., (2015) in India. In their study the highest prevalance was for Candidiasis followed by $\mathrm{BV}$ and Trichomoniasis. Namkinga et al., (2005) in Tanzania found the highest prevalent of Trichomoniasis followed by BV and then candidiaisis. In this study the prevalence of mixed infection (BV and Candida) was $10.4 \%$ which was lower (30.43\%) than the result of study done by Lamichanne et al., 2014. This change in the trend might be due to the differences in the living standards, socio-cultural status, hygienic condition, awareness towards their health, education and so on

Bacterial vaginosis (BV) is mostly present without signs and symptoms. The most common clinical signs and symptoms of BV is thin white or grey homogenous vaginal discharge with or without unpleasant smell and increased vaginal $\mathrm{pH}$. The smell of discharge is mostly noticed after sexual intercourse. Due to certain laboratory conditions BV was identified on the basis of Amsel's criteria. Out of 66positive cases of BV $93.9 \%$ had specific vaginal discharge, $84.8 \%$ had $\mathrm{pH}>4.5,84.8 \%$ had positive whiff test and $45.4 \%$ had clue cells. The differences between the incidences of these criteria and presence of $\mathrm{BV}$ were highly significant, $\mathrm{p}=0.00(\mathrm{p}<0.05)$.

In this study prevalence of BV was found to be $49.3 \%$ which is higher than in the study by Lamichanne et al., 2014 (39.13\%) and lower than in study done by Shrestha et al., 2011 (52.6\%). The prevalence of BV in this study was contrary to the result from study done by Narayankhedkar et al., 2015 in India. In his study, the prevalence of BV was only $17.3 \%$. The finding was higher than the study conducted by Gutman et al., (2005) in USA (38.7\%), Garcia et al., (2006) in Peru (39\%), Mathew et al., (2001) in Chennai (38.5\%), Patrica et al., (2006) in Peru (35.7\%) and lesser than the study conducted by Bhargav et al., (2016) in Nepal (54.3\%), Amatya et al., (2013) in Nepal (81.32\%).These variations may be because of difference in study population, economic status, educational background and method used for detection of $\mathrm{BV}$.

After BV, Vulvovaginal candidiasis (VVC) was found to be the second most common type of vaginitis. It is a common clinical problem that affects most adult women atleast once during their lifetime. The prevalence of VVC in this study was found to be $40.3 \%$ which is similar to most of the studies. In the study done by Narayankhedkar et al., 2015, VVC was the highly identified infectious vaginitis but the prevalence rate was lower $(30 \%)$ than that of our study $(40.3 \%)$. The 
prevalence of VVC in this study was higher than the result by Basnet (2004) in Nepal (16.12\%), Lamichhane (2014) in Nepal (30.43\%), Shrestha et al., (2014) in Nepal (15.1\%) and Bhargav et al., (2016) in Nepal (28.8\%), Prakash and Yadav (2016) in Nepal (35\%) and lower than the study conducetd by Rania et al., (2014) in Sudan (73\%) and Azzam et al., (2002) in Venezuela (84.2\%).

The distribution of Candida species identified in women with VVC varies widely depending on the locations as well as the population studied. The findings were also contrary to the findings of research by Schwiertz et al., (2006) in Germany (49.5\%). Antibiotic can upset the normal balance in the vagina and cause yeast overgrowth. Hormonal changes, use of birth control pills and menstruation can also cause yeast to grow.

In this study, there was no any positive case of Trichomoniasis which was similar to the study of Lamichanne et al., 2014. On the contrary, a number of studies have reported higher prevalence of Trichomoniasis like in the study conducted by Namkinga et al., (2005) in Tanzanai, Fule et al., (2012) in India. In the study conducted by Shrestha et al., 2011, prevalence of Trichomoniasis was 3.6\% Bhargav et al $20162.6 \%$ and Amatya et al., 2013 13\% These variations may be because of different study population, personal hygiene practice, environment and socioeconomic status and the method used for detection of Trichomoniasis. Moreover, the detection of TV by conventional wet mount method in the present study might have reduced the actual prevalence.

Mixed infection was also seen in this study and among which the prevalence of $\mathrm{BV}$ and VVC (10.4\%) being the dominant. Similar result was also obtained in the research conducted by Lamichanne et al., 2014 in Nepal (30.43\%), Shrestha et al.,2016 (7.2\%),
Bhargav et al., 2016 (18.1\%) and Schwiertz et $a l$., in 2006. The polymicrobial infection including all three (BV, VVC and trichomoniasis) types of infection was absent in this study. Two or more of these infections may co-exist so that the presenting signs and symptoms may not always be typical. This change in trend might be due to the differences in the living standards, sociocultural status, hygienic condition, awareness towards their health, education and so on.

In this study, 400 vaginal swabs were obtained from females of age 15 to 60 years. Out of 134 positive cases, the infection rate was highest among females of age group 21$30(68.7 \%)$ and least for age group 41-50 and 50 above. However, the difference was statistically in significant, $\mathrm{p}=0.07(>0.05)$. The obtained result was similar to the result of Shrestha et al., 2011 in Nepal, according to which occurrence of vaginitis was highest in age group 20-29 (41.8\%) followed by 30-39 (40\%). The BV was high in age group 21-30 (78.7\%) which was similar to the result obtained from study of Lamichanne et al., (2014) and Bhargav et al., (2016) and least in age group above 40 years. Similarly, Manandhar et al., (2005) observed the highest rate of vaginitis among the age group 25-29 and least below 20 years which was consisitent to the above study. According to this study, VVC was highest among age group 21-30 (62.9\%) and least in 41-50 age groups which was contrary to the study done by Bajracharya (2004) and Prakash and yadav (2016) where prevalence was highest among age group 20-25 and least in 35-40.

The elevated rate of infection in the age from 21-41 might be due to the age being most reproductively active age group and high sexual exposure at this age. According to Kent (1991), sexually active women have low vaginal defense mechanism against Candida species and use of contraceptives is also high 
at this age which is one of the predisposing factors of VVC.

Out of 400 urine sample processed which were collected from same females from whom HVS was collected, 58 (14.5\%) had UTI. The result was similar to the result of Lamichhane et al., (2011). But the study was contrary to the study done by Amatya et al., (2013) in Nepal (61.8\%), Aiyegaro et al., (2007) in Nigeria (77.8\%), Nahar et al., (2010) in Dhaka (60.7\%) and Lafi (2010) in Sulaimani (74\%). Host factor such changes in normal vaginal flora, trauma and introduction of perineal flora into urinary tract may also affect the risk of UTI in women.

The urine samples were collected from females of age 15-60 years. The infection rate was high among females of age group 21-30 $(55.17 \%)$ and least among age group 41-50. However, the difference was statistically insignificant.

The result was similar to the result by Lawani et al., (2015) where highest prevalence was seen in age group 24-28. But the study was contrary to the study of Majula et al., where highest prevalence was seen in age 31-40 years and Bano et al., (2011), Ojo et al., (2011) where UTI prevalent age group was 23-30. According to most of the studies most prevalent age group is from 21-30. This might be because of the age being sexually active age in females and lots of hormonal changes takes place during this age.

Among 58 bacterial isolates, 50 (89.3\%) were gram negative bacilli and $8(10.7 \%)$ were Gram positive cocci. In the study done by Shrestha et al., (2007), 93.7\% of the isolates were gram negative bacilli and $6.3 \%$ of them were Gram positive cocci. Gram negative bacilli were the major causative agent of UTI in studies done by Cruz et al (2009), Jha et al., (2009), Janifer et al., (2009).
Out of 58 bacterial isolates, 4 different species were isolated from 400 urine samples. The bacterial isolates were E.coli, Klebsiella spp, Enterobacter spp, and Staphylococcus spp. E.coli was the most $(39.2 \%)$ isolated bacteria followed by Klebsiella spp $28.5 \%$, Enterobacter spp 21.4\%, Staphylococcus spp $10.7 \%$. Higher prevalence of E.coli in this study was similar to the study done by Sheiner et al., (2009), Rahman et al., (1990), Ahmed et al., (1996), Mausbau et al., (2013). This could be due to the fact that uropathogenic E.coli express a multiple of virulence factors to break the inertia of the mucosal barrier and can persist with in urinary tract serving as a reserviour for recurrent infection and serious complication. Klebsiella spp was isolated as the second most common bacteria causing UTI. It accounts for $28.5 \%$. The result was similar to the finding by Das et al., (2006), Manadhar et al., (2005). Enterobacter was found to be the $3^{\text {rd }}$ most isolated Gram negative bacilli in present study. Among gram positive cocci, Staphylococcus was the only isolated organism. In this study, the incidence was found to be $10.7 \%$ of total bacterial isolates.

Increasing multidrug resistance in bacterial uropathogens is an important and emerging public health problem. Therefore, selection of drugs for treatment and susceptibility testing is most important. In present study, the purpose of antibiotic susceptibility testing for UTI is to know the susceptibility pattern of bacterial isolates causing UTI. Among gram negative isolates, $E$ coli was the most predominant organism and was highly resistant to Ampicillin (81.8\%) followed by Nalidixic acid $(72.7 \%)$. The organism was highly susceptible to Nitrofurantoin (100\%) followed by Amikacin (72.7\%).

Among 4 isolates of Gram positive organisms, the most effective drug was found to be Gentamycin with $100 \%$ susceptibility 
followed by Amikacin 75\%. Least effective drug was Penicillin and Cotrimoxazole with sensitivity of $0 \%$ and $25 \%$ respectively. Vancomycin also shows $100 \%$ sensitivity towards the Gram positive isolates. Similarly, in the study conducted by Hasan et al., (2007) Staphylococcus aureus was found $100 \%$ susceptible to Vancomycin which was in harmony with the present study. The wide spread and inappropriate use of antibiotics is recognized as a significant contributing factor to the spread of bacterial resistance and the development of resistance to antimicrobial agents (Shrestha et al., 2007).

From this study a strong association of UTI with vaginitis was established. Out of 134 women who had vaginitis, 36 (26.8\%) had coinfection with UTI. The association was statistically significant. Similar finding was seen in study done by Harmanli et al., in 2000, Hooton et al., in 1988 and Lam et al., in 1988.

Out of 66 cases of BV, 14 (21.2\%) cases were associated with UTI. The result was similar to that of Harmanli et al., in 2000 where $22.4 \%$ had both BV and UTI. Similarly, according to Lamichhane et al., (2014) out of 64 cases of BV, 23.4\% had UTI. In study conducted by Hillerbrand et al., out of $140 \mathrm{BV}$ positive cases, $13.6 \%$ had UTI. Although anatomical proximity allows easy transfer of G.vaginalis from the genital tract to the urinary tract but due to only a few investigators have examined the role G. vaginalis which is apotent cause of $\mathrm{BV}$, in UTI and renal disease.

Increase in $\mathrm{pH}$ of vagina because of the reduction in the vaginal lactobacilli might be one of the reasons for association between UTI and BV. The lactic acid and hydrogen peroxide are able to inhibit the growth of potential pathogens because they are toxic to many bacterial species. In addition lactobacilli produce bacteriocins that are active against a wide range of bacteria and fungi. So, once the ecology of vagina is disturbed during $\mathrm{BV}$, allowing colonization of potential uropathogens, the patients becomes more susceptible to UTI.

Our finding about association between BV and UTI was in contrary to the findings of research done by Amatya et al., where in 135 cases of BV $75 \%$ had associated UTI. In this study the association of UTI and BV was statistically insignificant. Variation in study population size may be one of the reasons for different result.

Similarly, in this study, among 54 candida positive cases, $18(33.3 \%)$ had associated UTI. The association was statistically significant $(\mathrm{p}<0.05)$. According to the research done by Amatya et al., 46\% were associated with both VVC and UTI. The published literature was lacking in studies investigating their relationship.

Considering age, UTI and BV both were high in females of age group 21-40. The reason for this may be because of the age being sexually active age in females and lots of hormonal changes takes place during this age. The increased frequency of coitus per week was found to a common risk factor for both UTI and vaginitis.

The imbalance created in vaginal microflora by exogenous factor in semen, facilitate development of BV. The urethral massage during the sexual activity has a facilitating role in moving the urethral colonizers into the bladder.

The differences inliving standards, sociocultural practices, personal hygiene, education and awareness of the individual may be the reasons for the differences seen in the incidence of UTI in vaginitis in different communities. 


\section{References}

Amatya R, Bhattarai S, Mandal PK, Tuladhar H, Karki BMS (2013). Urinary Tract Infections in vaginitis: a condition overlooked. Nep. Med. Coll J 2013; 15 (1): 65-67.

Bhargav D, Kar S, Saha M, Saha A (2016). Indian $\mathrm{J}$ of Med Resc and Pharm Sci. 3(7): 39-43.

Blackwell's Nursing dictionary (2nd edition). Blackwell publishing Ltd 2005; 642.

Bradshaw S, Morton A, Garland M, Morris B. Moss L, Fairley CK(2005). Higher-Risk behavioral practices associated with bacterial vaginosis compared with vaginal candidiasis. Obstet Gynecol.106(1):105-114.

Cheesbrough M (2000) Medical laboratory manual for Tropical countries 2: 129390

Das-Neves J., Pinto E., Teixeira B., Dias G., Rocha P. and Cunha T. (2008).

Local treatment of vulvovaginalcandidosis: general and practical

considerations. Drugs 68 (13): 1787-802.

Eckert LO (2006). Acute vulvovaginitis. N Engl J Med. 335: 1244-52.

Eschenbach DA (2004) Chronic vulvovaginal candidiasis. New England Journal of Medicine 351: 851-85

Ferrer J. (2000). Vaginal candidosis: epidemiological and etiological factors.

Forbes BA, Sahm DF, Weissfeld AS, Bailey WR (2007). Bailey and Scott's diagnostic Microbiology, 12th edition. St. Louis, MO: Elsevier Mosby, pp.842856

Gillespie SH (1994) Medical Microbiology Illustrated: Investigation of specimens from the genital tract and diagnosis of STDs. First edition Butterworthheinmann Ltd, pp 230-233

Gutman RE, Peipert JF, Weitzen S and Blume J (2005) Evaluation of clinical methods for diagnosing bacterial vaginosis.
ObstetGynecol105(3): 551-556

Gynae of India 38(3): 125-128

Harmanli OH, Cheng Gy, Nyirjesy P, Chatwani A, Gaughan JP (2000). Urinary Tract Infections In Women with bacterial vaginosis. Am. Coll. Obstet.Gynecol. 95(5): 710-712

Jha N, Bapat SK (2005). A study of sensitivity and resistance of pathogenic microorganisms causing UTI in Kathmandu valley. KUMJ. 3(2:10): 123-129

Kamara P, Hylton-kong T, Brathwaite A, DelRosaria GR, Kristensen S, Patrick N, Weiss H, Figueroa PJ, Vermund SH and Jolly PE (2000) Vaginal infections in pregnant women in Jamaica: prevalence and risk factors. International Journal of STDs and AIDS 11(8): 516-520

Lamichhane P, Joshi DR, Subedi YP, Thapa R, Acharya GP, Lamsal A, Upadhaya S Pokhrel S (2014). Study on types of vaginitis and association between bacterial vaginosis and urinary tract infection in pregnant women. International Journal of Biomedical and Advance Research. 05 (06): 304-07

Monif GR (1985) Classification and pathogenesis of vulvovaginal candidiasis. Am J ObstetGynecol152: 935-939

Namkinga LA, Matee MI, Kivaisi AK and Moshiro C (2005) Prevalence and risk factors for vaginal candidiasis among women seeking primary care for genital infections in Dar es Salaam, Tanzania. East Afr Med J 82(3): 138-143

Narayankhedkar A, Hodiwala A, Mane A (2015). Clinicoetiological Characterization of Infectious vaginitis amongst Women of reproductive age group from Navi Mumbai, India. Journal of Sexually Transmitted Disease. Vol 2015. Research article

Noor N, Ajaz M, Rasool SA, Pirzada ZA (2004). Urinary tract infections 
associated with multidrug resistant enteric bacilli: characterization and genetical studies. Pak J Pharm Sci. 17/2: $115-23$.

Owen MK and Clenney TL (2004) American Family Physician: Vaginitis. A peer reviewed journal of the American Academy of family physicians 70(11): 2125-2132

Patricia JG, Cesar PC, Marina C and Holmes KK (2006) Sexually transmitted and reproductive tract infections in symptomatic clients of pharmacies in Lima, Perú. Bulletin of World health Organization 82 (7): 483-490.

Pradhan P (2003) Vulvovaginal Candidiasis. Nepal medical college Journal 3(2): $122-126$

Prakash S, Yadav K (2015). Prevalence of Vulvovaginal Candidiasis in pregnancy, Nepal. Glob. J. Med. Med. Sci4(1); 108116

Prasad JH, Abraham S, Kurz KM, George V, Lalitha MK, John R, Jayapaul MNR, Shetty N and Joseph A (2005) Reproductive tract infections among young married women in Tamil Nadu, India. International Family Planning Perspectives 31(2): 73-81
Prospero FD: Focus on candida, trichomonas, bacteria and atrophic vaginitis. Available at http://womanhealthgate.com/focuscandida-trichomonasbacteria-atrophicvaginitis/ on July 10, 2014

Shrestha S, Tuladhar NR, Basnyat S, Acharya GP, Shrestha P, Kumar P (2011). Prevalence of vaginitis among pregnant women attending Paropakar Maternity and Women's Hospital, Thapathali, Kathmandu, Nepal. Nepal Med CollJ.13(4): 293-296

Tansarli, G. S.; Kostaras, E. K.; Athanasiou, S.; Falagas, M. E. (2013). "Prevalence and treatment of aerobic vaginitis among non-pregnant women: evaluation of the evidence for an underestimated clinical entity". European Journal of Clinical Microbiology \& Infectious Diseases. 32 (8): 977-84.

Zhou X, Bent SJ, Schneider MG, Davis CC, Islam MR, Forney LJ. (2004). Characterization of vaginal microbial communities in adult healthy women using cultivation-independent methods. Microbiology 150: 2565-2

\section{How to cite this article:}

Ravi Shankar Gupta, Dipak Bhargav and Jagat Prasad Deep. 2021. Common Types of Vaginitis (Bacterial Vaginosis, Vulvovaginal Candidiasis, Trichomoniasis) and their Association with Urinary Tract Infection among Women Visiting NMCTH, Birgunj. Int.J.Curr.Microbiol.App.Sci. 10(01): 996-1010. doi: https://doi.org/10.20546/ijcmas.2021.1001.121 